\title{
Genotoxicity effects on Geophagus brasiliensis fish exposed to Doce River water after the environmental disaster in the city of Mariana, MG, Brazil
}

\author{
L. C. Gomes ${ }^{a}$, A. R. Chippari-Gomes ${ }^{a}$, T. O. Miranda ${ }^{a}$, T. M. Pereira ${ }^{a}$, J. Merçon ${ }^{a}$, \\ V. C. Davel ${ }^{a}$, B. V. Barbosa ${ }^{a}$, A. C. H. Pereira ${ }^{a}$, A. Frossard ${ }^{a}$ and J. P. L. Ramos ${ }^{a}$ \\ ${ }^{a}$ Laboratório de Ictiologia Aplicada - LabPeixe, Universidade Vila Velha - UVV, \\ Avenida Comissário José Dantas de Melo, 21, Boa Vista, CEP 29102-920, Vila Velha, ES, Brasil \\ *e-mail: niktati@gmail.com
}

Received: November 20, 2017 - Accepted: February 20, 2018 - Distributed: November 30, 2019

(With 2 figures)

\begin{abstract}
The Doce River basin has suffered the largest environmental accident ever occurred in Brazil with the influx of tailings from Fundão and Santarém, belonging to Samarco mining company, due to the disaster in Mariana. A spill between 50 and 60 million $\mathrm{m}^{3}$ of tailings was estimated by the company. According to Samarco, the wastewater was composed mainly of clay, silt and heavy metals like iron, copper and manganese. Thereby, the objective of the present study was evaluated the genotoxic damage in juvenile of Geophagus brasiliensis (Quoy e Gaimard, 1824) exposed to Doce river water before (DRWBA - Doce River water before acident) and after (DRWAA - Doce River water after acident) the influx of tailings from the Germano and Santarém Dam disasters in Mariana, MG, Brazil. For this, 24 individuals of the species G. brasiliensis (obtained on IFES/ALEGRE fish culture) were submitted to a bioassay with three treatments and eight replicates. The treatments were: 1) Control water (water from the urban water supply system, filtered with a $0.45 \mu \mathrm{m}$ membrane), 2) DRBA and 3) DRAA. After $96 \mathrm{~h}$, these fishes were anesthetized to remove blood for evaluation of genotoxic damage (micronucleus and comet). For the bioassay, a total of $80 \mathrm{~L}$ of The Doce River water were collected before the influx of tailings and after the influx and then submitted to metal quantification analysis. Fish exposed to DRWBA and DRWAA treatments showed a significant increase in both the number of erythrocyte micronuclei and the DNA damage index in relation to the control fish; however, they did not present any differences between the two treatments. The results demonstrate that the DRWBA treatment was already genotoxic for the fish, mainly due to dissolved $\mathrm{Cu}$ concentrations in the water. The DRWAA treatment probably presented genotoxicity due to the increase in the dissolved fraction and synergistic effects of several metals found in the tailings of the Mariana accident.
\end{abstract}

Keywords: micronuclei, comet assay, heavy metal, fish, Doce River.

\section{Efeitos da genotoxicidade em peixes da espécie Geophagus brasiliensis expostos a água do Rio Doce após o desastre ambiental na cidade de Marina, MG, Brasil}

\section{Resumo}

A bacia do Rio Doce sofreu o maior acidente ambiental com o influxo de rejeitos de Fundão e Santarém, pertencentes à empresa de mineração Samarco, devido ao desastre em Mariana. Um derramamento entre 50 e 60 milhões de $\mathrm{m}^{3}$ de rejeitos foi estimado pela empresa. De acordo com a Samarco, o rejeito despejado era composto principalmente de argila, silte e alguns metais pesados como ferro, cobre e manganês. Com isso, o presente estudo teve como objetivo avaliar os danos genotóxicos em juvenis de Geophagus brasilienses expostos a água do rio Doce antes (DRWAA - água do Rio Doce antes do acidente) e depois (DRWBA- água do Rio Doce depois do acidente) da chegada dos rejeitos do rompimento das barragens de Germano e Santarém em Mariana, MG, Brasil. Para isso, 24 indivíduos da espécie G. brasilienses (obtidos na piscicultura do IFES/ALEGRE) foram submetidos a um bioensaio com três tratamentos e oito réplicas. Os tratamentos eram: 1) Controle (com água do abastecimento urbano, filtrada com filtro analítico de 0,45 $\mu \mathrm{m}$ ); 2) DRWBA e 3) DRWAA. Após um período de $96 \mathrm{~h}$, esses peixes foram anestesiados para retirada de sangue para avaliação dos danos genotóxicos (micronúcleo e cometa). Para a realização do bioensaio, um total de $80 \mathrm{~L}$ de água do Rio Doce foram coletados antes da chegada dos rejeitos e outros $80 \mathrm{~L}$ foram coletados depois da chegada dos rejeitos e ambas foram submetidas a análises de quantificação de metal. Os peixes expostos ao DRWBA e ao DRWAA apresentaram um aumento significativo na quantidade de micronúcleos eritrocitários e no índice de danos do DNA em relação aos peixes controle, no entanto não apresentaram diferenças entre si. Os resultados obtidos demonstram 
que a DRWBA já era genotóxica para os peixes, principalmente, em função das concentrações de Cu dissolvido na água. A DRWAA apresentou genotixicidade, provavelmente, em função do aumento da fração dissolvida e do efeito sinérgico de diversos metais presentes nos rejeitos do acidente de Mariana.

Palavras-Chave: micronucleo, ensaio cometa, metal pesado, peixes, Rio Doce.

\section{Introduction}

The Doce River basin has suffered the largest environmental accident ever occurred in Brazil with the influx of tailings from Fundão and Santarém, belonging to Samarco mining company, due to the disaster in Mariana. The dams were situated on the estern part of the Ferriverous Quadrangle (FQ), in the northwest portion of the Mariana-MG, at the foot of the Batatal mountain ranges $(1,700 \mathrm{~m}$ of altitude) and Coqueiro mountain $(1,796 \mathrm{~m}$ of altitude), between Serra do Caraça (North) and Serra de Antônio Pereira (South) (USP, 2015). The municipality area is $1,194 \mathrm{~km}^{2}$, where more than 58,000 people are living in rural and urban zones (IBGE, 2015). The FQ is a very important geologic and economic region. It has approximately $7,000 \mathrm{~km}^{2}$, extending from the city of Ouro Preto to Belo Horizonte (Ruchkys, 2009). On November $5^{\text {th }}, 2015$, Samarco's dam called Fundão burst causing an enormous environmental disaster. The mudslide reached other dam called Santarém and flowed to Bento Rodrigues, a sub-district destroyed by the mud. More than $80 \%$ edifications were covered by mud. After, mud flowed to the rivers Gualaxo do Norte, Carmo and Doce and then the Atlantic Ocean on November 22 $2^{\text {nd }}, 2015$ (Segura et al., 2016). A spill of 50 - 60 million $\mathrm{m}^{3}$ meters of tailings was reported by the company (Marta-Almeida et al., 2016; Gomes et al., 2017). According to Samarco, this residue was composed mainly of clay and silt (Escobar, 2015). As a result of the disaster, metals contained in the tailings were released into the waters of the Doce River.
In recent years several studies have evaluated the impact of metals as genotoxic pollutants. At the molecular level, the comet assay and the micronucleus test (MN) are complementary biomarkers for genotoxic testing and indicate significant DNA damage based on two different endpoints (Rudolf and Cervinka, 2006; Villela et al., 2006; Medeiros et al., 2017). Micronuclei arise from chromosomal fragments or whole chromosomes that are not incorporated into daughter nuclei at mitosis (Schmid, 1975) and could be easily visualised in peripheral erythrocytes (Omar et al., 2012), whereas the alkaline comet assay measures strand breaks before the DNA repair systems intervene (Medeiros et al., 2017; Scalon et al., 2010).

Therefore, it is necessary to evaluate the toxic effects of the tailings from the Mariana accident on fish in the Doce River. The objective of this work was to verify the acute genotoxic effects in $G$. brasiliensis, a native species to the Doce River basin and exposed to the waters of the lower Doce River, which were contaminated by the tailings from the disasters in Mariana, MG.

\section{Materials and Methods}

\subsection{Water collection}

The influx of tailings from Fundão e Santarém, belonging to Samarco mining company, occurred on 11/11/2015. The collection of water from the Doce River for the present study was conducted in Colatina, ES, approximately $500 \mathrm{~km}$ from the rupture site of the dams, and $98 \mathrm{~km}$ from the Doce River estuaries (Figure 1). The water collection

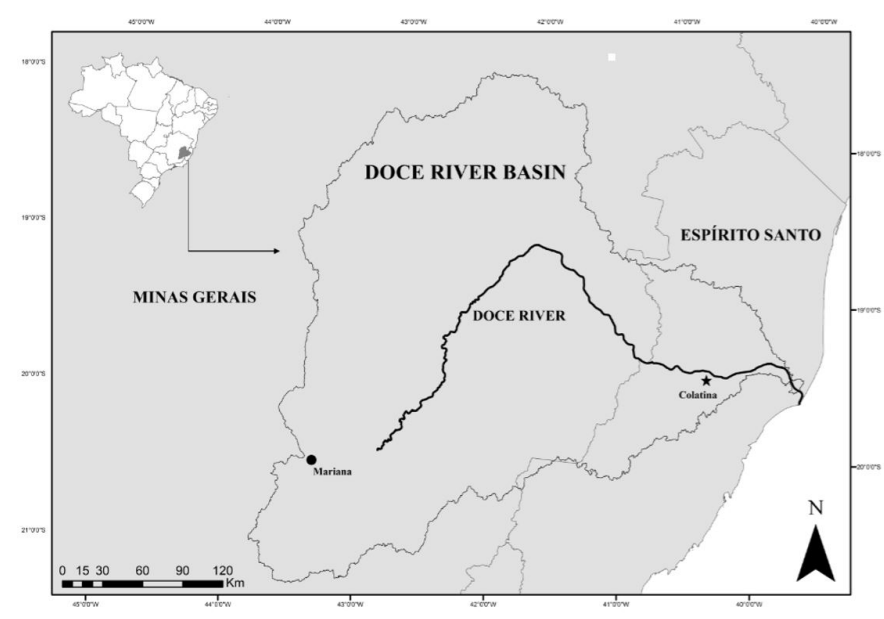

Figure 1. Map showing the influx of tailings from the Fundão and Santarém Dams disasters in Mariana, along Doce River (MG and ES, Brazil). The water collection from the Doce River for the present study (before and after the accident) was conducted in Colatina (Espírito Santo), approximately $500 \mathrm{~km}$ from the rupture site of the dams, and $98 \mathrm{~km}$ from the Doce River estuaries. 
was carried out at two separate times: before the tailings from the accident reached Colatina (09/11/2015) and $24 \mathrm{~h}$ after the tailings visually reached Colatina (11/20/2015). The samples were refrigerated at $4{ }^{\circ} \mathrm{C}$ until analysis. The experiment began on 11/21/2015. A total of $80 \mathrm{~L}$ of The Doce river water were collected before the influx of tailings and after the influx reached Colatina.

\subsection{Bioassay}

Juveniles of $G$. brasiliensis ( $4.8 \pm 0.3 \mathrm{~g}$; mean \pm STD) were obtained from IFES (Alegre campus). This research was approved by the UVV Ethics and Animal Welfare Commission (No. 371-2016). The fishes were less than a year old and were not maturated yet. After identification, the voucher specimen was deposited in the ichthyological collection of the Museu de Biologia Professor Mello Leitão, Santa Teresa - ES (MBML - PEIXES 12643). The choice of the specie was due to the high occurrence in the Brazilian rivers, including Doce River. Fish were previosly acclimated to laboratory conditions for 30 days in a $300 \mathrm{~L}$ tank, with the use of filtration and continuous aeration systems. During this period fish were daily fed until satiety with commercial extruded fish ration with $45 \%$ of crude protein (Propescado - Nutriaves). Twenty-four individuals were transferred to individual aquariums $48 \mathrm{~h}$ before the experiment. The aquariums had 6 L capacity each and were filled with $5 \mathrm{~L}$ of control water, and constant aeration was performed by a pump with porous stone diffusion $\left(\mathrm{OD}>6.0 \mathrm{mg} \mathrm{L}^{-1}\right.$; Temperature $\left.=25.8 \pm 0.4^{\circ} \mathrm{C}\right)$. At the beginning of the experiment, a full exchange of the control water with the exposure water was performed. An entirely randomized experiment with three treatments and eight replicates (with 1 fish in each aquarium) was carried out. The treatments were: 1) control water (water from the urban water supply system, filtered with a $0.45 \mu \mathrm{m}$ membrane); 2) water from the Doce River before the influx of the tailings (DRWBA); and 3) water from the Doce River containing the tailings from the Mariana accident (DRWAA). After $96 \mathrm{~h}$ of exposure, the fish were anesthetized by immersion in a $200 \mathrm{mg} \mathrm{L}^{-1}$ Benzocaine solution, and blood was then drawn from the caudal vein for genotoxic analysis. The quantification of total metal and the $\mathrm{pH}$, conductivity and total suspended solids of the three treatments were also analyzed

\subsection{Genotoxicity assays}

Micronuclei quantification was performed according to Al-Sabti and Metcalfe (1995) and Medeiros et al. (2017), using a Giemsa stain (5\% w/v). One thousand erythrocytes per fish were analyzed under an optical microscope (100x magnification). Only intact cells with distinct nuclear and cellular membranes were scored. The alkaline Comet assay was performed as described by Tice et al. (2000), Cariello Delunardo et al. (2013) and Medeiros et al. (2017) using silver nitrate. The Blood samples were diluted 1:120 (v:v) in RPMI 1640 medium for the alkaline comet assay. All sides were blind-reviewed, and the extent of DNA was quantified by the lengh of DNA migration (Tice et al., 2000; Cariello Delunardo et al., 2013; Medeiros et al., 2017). A total of 100 cells from each fish were randomly analyzed using optical microscopy (100x magnification) to measure the length of the comet's tail (Tice et al., 2000; Cariello Delunardo et al., 2013; Medeiros et al., 2017). The DNA damage was classified into four classes according to Kobayashi et al. (1995) as follow: (o) no damages, (1) short tail smaller than the diameter of the nucleus, (2) a tail length 1-2 fold the diameter of the nucleus and (3) a tail length $>2$-fold the diameter of the nucleus. The results were expressed as the mean of damage index (DI). The DI was executed by multiplying the number of cells in each class by the damage class and ranged for 0 (no damage) to 300 (maximally damage).

\subsection{Quantification of water metal}

Four samples of water from each treatment were collected before the beginning of the experiment and filtered through a $0.45 \mu \mathrm{m}$ filter for analysis of $\mathrm{Cd}, \mathrm{Cu}, \mathrm{Fe}, \mathrm{Mn}$, and $\mathrm{Pb}$. Additionally, four samples of the RDWAA were digested at $95{ }^{\circ} \mathrm{C}$ in nitric acid for analysis of the total metal content. The analyses were carried out in an atomic absorption spectrophotometer (AAS - Thermo ICE 3500) with a graphite furnace. For all metals, the correlation coefficients of the standard curves were higher than 0.99 , and $b$ of the equations were close to zero.

\subsection{Statistical analyses}

Data about genotoxicity were previously checked for normality and homogeneity of variances. Micronuclei did not show a normal distribution and were Log-transformed before analysis. Data were expressed as the mean \pm STD and analyzed by one-way ANOVA, followed by the Tukey test $(\mathrm{p}<0.05)$.

\section{Results}

The physical parameters values were higher in the DRWBA and DRWAA treatments than in the control treatment (Table 1). An increase in suspended solids in the river after the mud flow was evident, and it was almost 500 times greater than before the passage. Likewise, dissolved metals, except $\mathrm{Cu}$, were present in higher concentrations in the DRWAA treatment. The concentration of dissolved $\mathrm{Fe}$ and $\mathrm{Mn}$ was greater in the DRWAA treatment compared to the control and DRWBA treatments. The concentration of $\mathrm{Cu}$ was higher in the DRWBA treatment than in the control and DRWAA treatments. The concentrations of metals were higher in both DRWBA and DRWAA when compared to CONAMA 357/2005 standard values (Table 1). The micronuclei and the comet showed similar results: a significant increase in both factors when the fish were exposed to the DRWBA and DRWAA water treatments compared to the control treatment. Compared to the control treatment the micronuclei increase in 3.5\% and the comet increase in $120 \%$ as shown in figure 2 .

\section{Discussion}

The results found in the present study could be related to the water collection site. In Colatina, a large industrial pole is present on the margins of the Doce River that uses copper in its processes, such as within the textile 
Table 1. Water quality during exposure of G. brasiliensis to Doce River water before and after Mariana disaster. Data were presented as mean $\pm \mathrm{STD}$. Metals were presented in dissolved form (45 $\mu \mathrm{m}$ filtered). To obtain DRWAA total metal, samples were digested before analysis. Cond. = Conductivity; DRWBA = Doce river water before accident; DRWAA = Doce river water after accident.

\begin{tabular}{cccccc}
\hline Parameter & $\begin{array}{c}\text { Control } \\
\text { water }\end{array}$ & DRWBA & DRWAA & $\begin{array}{c}\text { DRWAA } \\
\text { Total Metal }\end{array}$ & *CONAMA \\
\hline $\mathrm{pH}$ & $7.1 \pm 0.1$ & $7.4 \pm 0.1$ & $7.1 \pm 0.2$ & - & $6.0-9.0$ \\
$\mathrm{Cond} .\left(\mu \mathrm{S} . \mathrm{cm}^{-1}\right)$ & $106 \pm 5.1$ & $117 \pm 3.2$ & $147 \pm 3.1$ & - & - \\
$\mathrm{TSS}\left(\mathrm{mg} \cdot \mathrm{L}^{-1}\right)$ & $<\mathrm{DL}$ & $2.20 \pm 0.6$ & $1.185 \pm 84$ & - & - \\
$\mathrm{Cd}\left(\mu \mathrm{g} \cdot \mathrm{L}^{-1}\right)$ & $<\mathrm{DL}$ & $<\mathrm{DL}$ & $<\mathrm{DL}$ & $0.20 \pm 0.1$ & $1 * *$ \\
$\mathrm{Cu}\left(\mu \mathrm{g} . \mathrm{L}^{-1}\right)$ & $1.56 \pm 0.41$ & $63.85 \pm 6.01$ & $3.90 \pm 0.80$ & $112.1 \pm 4.83$ & 9 \\
$\mathrm{Fe}\left(\mu \mathrm{g} . \mathrm{L}^{-1}\right)$ & $1.30 \pm 0.09$ & $1.32 \pm 0.11$ & $5.91 \pm 1.56$ & $19,800 \pm 2,010$ & 3,000 \\
$\mathrm{Mn}\left(\mu \mathrm{g} \cdot \mathrm{L}^{-1}\right)$ & $100.9 \pm 0.13$ & $128.3 \pm 0.51$ & $265.3 \pm 0.30$ & $3,610 \pm 710$ & $100 * *$ \\
$\mathrm{~Pb}\left(\mu \mathrm{g} . \mathrm{L}^{-1}\right)$ & $<\mathrm{DL}$ & $<\mathrm{DL}$ & $<\mathrm{DL}$ & $23.02 \pm 2.39$ & - \\
\hline
\end{tabular}

DL = Detection level; TSS $=$ Total of suspended solids; ${ }^{*}$ Resolution CONAMA 357/2005 standard values for dissolved metals in waters; **Total Metals.
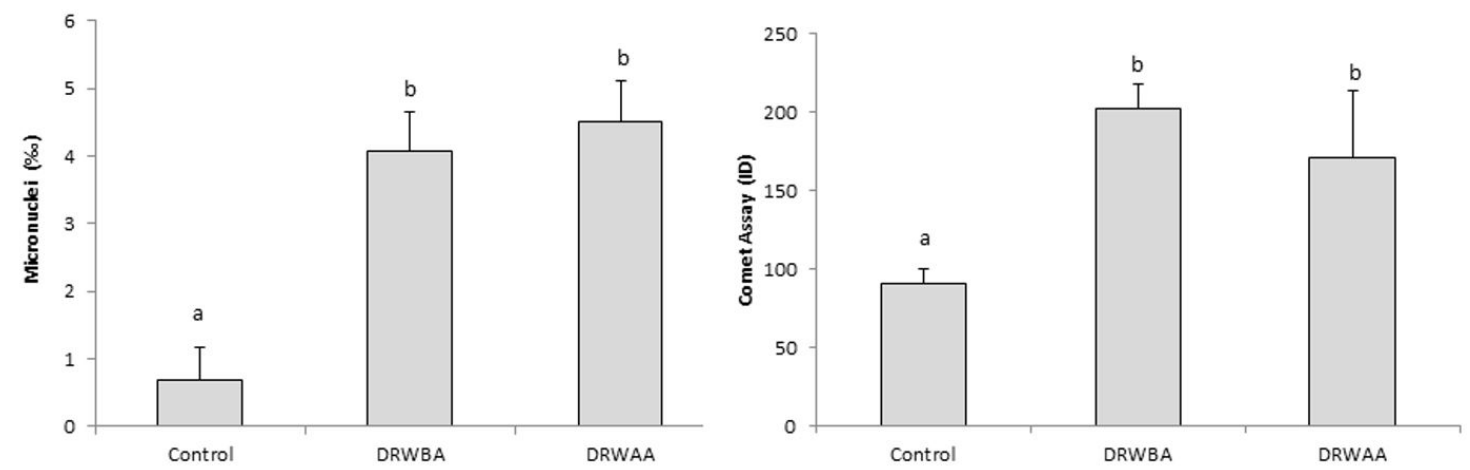

Figure 2. Micronuclei and Comet assay in Geophagus brasiliensis after acute exposure to Doce river water before and after Mariana disaster. Data were presented as mean \pm STD. Control = control water; DRWBA = Doce river water before accident; DRWAA = Doce river water after accident. Subscript letters indicate significant differences between treatments by one way ANOVA and Tukey test $(\mathrm{P}<0.05)$.

industry. Therefore, it is possible that the greatest quantity of dissolved $\mathrm{Cu}$ in the DRWBA treatment was related to the effluents of the local industry. The decrease in dissolved $\mathrm{Cu}$ in the DRWAA treatment could be related to the amount of clay and goethite present in the waters after the accident, since $\mathrm{Cu}$ has a high affinity for these compounds (Christophi and Axe, 2014). The results from the total metal analysis show that the DRWAA treatment had high concentrations of the analyzed metals, but in complex forms, which is also explained by the amount of clay and goethite present in the DRWAA treatment. According to Marta-Almeida et al. (2016) and Gomes et al. (2017), a total between $50-60$ million $\mathrm{m}^{3}$ of clay was deposited into the Doce River channel as a result of the accident. Additionally, Pires et al. (2003) reported that goethite composes approximately $69.5 \%$ of Samarco's solid waste.

The genotoxic analyses indicated that the Doce River water, even before the tailings from the accident, already presented genotoxic potential. These results may be verified by the concentration of dissolved $\mathrm{Cu}$ in the
DRWBA treatment. The genotoxicity of $\mathrm{Cu}$ is related to the induction of reactive oxygen molecules (ROS) and the resulting damage to the DNA molecule (Bagdonas and Vosyliené, 2016). Guecheva et al. (2001) explain that the genotoxicity of $\mathrm{Cu}$ can be caused by the affinity of this metal for amino acids, compared to nucleotides, thus leading to an inactivation of proteins involved in DNA processes. Similar concentrations of $\mathrm{Cu}\left(40-80 \mu \mathrm{g} \mathrm{L}^{-1}\right)$ have also been shown to be genotoxic for Oncorhynchus mykiss at acute exposure levels (Bagdonas and Vosylienè, 2016). The DRWAA treatment was also genotoxic for juvenile $G$. brasiliensis. The most probable reason for this is the synergistic effect of metals with increasing dissolved concentration of $\mathrm{Mn}$ and other metals not analyzed in this study, such as $\mathrm{Al}, \mathrm{Cr}, \mathrm{Zi}$, Va and $\mathrm{Ni}$, that also increased in the DRWAA treatment, as verified by Neto et al. (2016). To corroborate our hypothesis, Omar et al. (2012) observed that the synergistic effect of several metals $(\mathrm{Cu}, \mathrm{Pb}, \mathrm{Fe}$ and $\mathrm{Mn})$ at concentrations similar to those found in the present study were genotoxic 
for Oreochromis niloticus and Clarias gariepinus in a polluted lake in Egypt.

Escobar (2015) reports that due to the activities on its margins, the Doce River was already polluted before the disaster, which was confirmed in this work by the genotoxicity observed in fish exposed to water in the DRWBA treatment. However, the DRWAA treatment also presented a genotoxic potential for $G$. brasiliensis, which shows that the tailings from the accident also contributed harmful pollutants to the native fauna. Next, studies of chronic effects are needed to understand the long-term consequences of the Mariana disaster for biota.

\section{Acknowledgements}

We thank FAPES (no. 77683463/2017) for the financial support and IFES - Alegre due the fish donation. L.C.G is a recipient of a research fellowship from $\mathrm{CNPq} / \mathrm{Brazil}$.

\section{References}

AL-SABTI, K. and METCALFE, C.D., 1995. Fish micronuclei for assessing genotoxicity in water. Mutation Research/Genetic Toxicology, vol. 343, no. 2-3, pp. 121-135.

BAGDONAS, E. and VOSYLIENE, M.Z.A., 2016. Study of toxicity and genotoxicity of copper, zinc and their mixture to rainbow trout (Oncorhynchus mykiss). Biologija (Vilnius, Lithuania), no. 1, pp. 8-13.

CARIELLO DELUNARDO, F.A., FERREIRA DA SILVA, B., PAULINO, M.G., NARCISO FERNANDES, M. and CHIPPARIGOMES, A.R., 2013. Genotoxic and morphological damage in Hippocampus reidiI exposed to crude oil. Ecotoxicology and Environmental Safety, vol. 87, pp. 1-9. http://dx.doi.org/10.1016/j. ecoenv.2012.09.029. PMid:23116620.

CHRISTOPHI, C.A. and AXE, L., 2014. Competition of Cd, $\mathrm{Cu}$ and $\mathrm{Pb}$ adsorption on goethite. Journal of Environmental Engineering, vol. 126, no. 1, pp. 66-74. http://dx.doi.org/10.1061/ (ASCE)0733-9372(2000)126:1(66).

ESCOBAR, H., 2015. Mud tsunami wreaks ecological havoc in Brazil. Science, vol. 350, no. 6265, pp. 1138-1139. http://dx.doi. org/10.1126/science.350.6265.1138. PMid:26785449.

GOMES, L.E.O., CORREA, L.B., SÁ, F., NETO, R.R. and BERNARDINO, A.F., 2017. The impacts of the Samarco mine tailing spill on the Rio Doce estuary, Eastern Brazil. Marine Pollution Bulletin, vol. 120, no. 1-2, pp. 28-36. http://dx.doi. org/10.1016/j.marpolbul.2017.04.056. PMid:28477986.

GUECHEVA, T., HENRIQUES, J.A.P. and ERDTMANN, B., 2001. Genotoxic effects of copper sulfate in freshwater planariam in vivo, studied with the single-cell get test (comet assay). Mutation Research/Genetic Toxicology and Environmental Mutagenesis, vol. 497, no. 1-2, pp. 19-27. http://dx.doi.org/10.1016/S13835718(01)00244-3. PMid:11525904.

INSTITUTO BRASILEIRO DE GEOGRAFIA E ESTATÍSTICAIBGE. 2015 [viewed 21 September 2017]. Information of Brazilian Cities [online]. Available in: http://www.planejamento.gov.br/ acesso-a-informacao/auditorias/instituto-brasileiro-de-geografia-eestatistica-ibge/instituto-brasileiro-de-geografia-e-estatistica-2015
KOBAYASHI, H., SUGIYAMA, C., MORIKAWA, Y., HAYASHI, M. and SOFUNI, T., 1995. A comparison between manual microscopic analysis and computerized image analysis in the single cell electrophoresis. MMS Cоттu, vol. 3, pp. 103-115.

MARTA-ALMEIDA, M., MENDES, R., AMORIM, F.N., CIRANO, M. and DIAS, J.M., 2016. Fundão Dam collapse: Oceanic dispersion of River Doce after the greatest Brazilian envinronmental accident. Marine Pollution Bulletin, vol. 112, no. 1-2, pp. 359-364. http://dx.doi.org/10.1016/j.marpolbul.2016.07.039. PMid:27502362.

MEDEIROS, L.C.C., DELUNARDO, F.A.C., SIMÕES, L.N., PAULINO, M.G., VARGAS, T.S., FERNANDES, M.N., SCHERER, R. and CHIPPARI-GOMES, A.R., 2017. Water-soluble fraction of petroleum induces genotoxicity and morphological effects in fat snook (Centropomus parallelus). Ecotoxicology and Environmental Safety, vol. 144, pp. 275-282. http://dx.doi.org/10.1016/j.ecoenv.2017.06.031. PMid:28641238.

NETO, R., SÁ, F., SCHETTINI, E. and DACOL, B. 2016 [viewed 13 June 2017]. Geoquímica de metais e nutrientes [online]. http://www.icmbio.gov.br/portal/images/stories/ DCOM_geoquimica_soloncy_ufes.pdf.

OMAR, W.A., ZAGHLOUL, K.H., ABDEL-KHALEK, A.A. and ABO-HEGAB, S., 2012. Genotoxic effects of metal pollution in two fish species, Oreochromis niloticus and Mugil cephalus, from highly degraded aquatic habitats. Mutation Research, vol. 746, no. 1, pp. 7-14. http://dx.doi.org/10.1016/j.mrgentox.2012.01.013. PMid:22464984.

PIRES, J.M.M., LENA, J.C., MACHADO, C.C. and PEREIRA, R.S., 2003. Potencial poluidor de resíduo sólido da Samarco Mineração: Estudo de caso da Barragem de Germano. Revista Árvore, vol. 3, no. 3, pp. 393-397. http://dx.doi.org/10.1590/ S0100-67622003000300017.

RUCHKYS, U.A., 2009. Geoparques e a musealização do territorio: um estudo sobre o quadrilatero ferrífero. Geologia, vol. 5, pp. 35-46.

RUDOLF, E. and CERVINKA, M., 2006. The role of intracellular zinc in chromium (VI)-induced oxidative stress, DNA damage and apoptosis. Chemico-Biological Interactions, vol. 162, no. 3, pp. 212-227. http://dx.doi.org/10.1016/j.cbi.2006.06.005. PMid:16887109.

SCALON, M.C., RECHENMACHER, C., SIEBEL, A.M., KAYSER, M.L., RODRIGUES, M.T., MALUF, S.W., RODRIGUES, M.A. and SILVA, L.B., 2010. Evaluation of Sinos River water genotoxicity using the comet assay in fish. Brazilian Journal of Biology = Revista Brasileira de Biologia, vol. 70, no. 4, (suppl.), pp. 1217-1222. http://dx.doi.org/10.1590/ S1519-69842010000600011. PMid:21225163.

SCHMID, W., 1975. The micronucleus test. Mutation Research, vol. 31, no. 1, pp. 9-15. http://dx.doi.org/10.1016/0165-1161(75)900588. PMid:48190.

SEGURA, F.R., NUNES, E.A., PANIZ, F.P., PAULELLI, A.C.C., RODRIGUES, G.B., BRAGA, G.Ú.L., REIS PEDREIRA FILHO, W., BARBOSA JÚNIOR, F., CERCHIARO, G., SILVA, F.F. and BATISTA, B.L., 2016. Potential risks of the residue from Samarco's mine dam burst (Bento Rodrigues, Brazil). Environmental Pollution, vol. 218, pp. 1-13. http://dx.doi. org/10.1016/j.envpol.2016.08.005. PMid:27524249. 
TICE, R.R., AGURELL, E., ANDERSON, D., BURLINSON, B., HARTMANN, A., KOBAYASHI, H., MIYAMAE, Y., ROJAS, E., RYU, J.C. and SASAKI, Y.F., 2000. Single cell gel/comet assay: Guidelines for in vitro and in vivo genetic toxicology testing. Environmental and Molecular Mutagenesis, vol. 35, no. 3, pp. 206-221. http://dx.doi.org/10.1002/ (SICI) 1098-2280(2000)35:3<206::AID-EM8>3.0.CO;2-J. PMid:10737956.
UNIVERSIDADE DE SÃO PAULO - USP, 2015. Tremores de terra ocorridos em Mariana/ Bento Rodrigues. São Paulo: Centro de Sismologia USP.

VILLELA, I.V., OLIVEIRA, I.M., SILVA, J. and HENRIQUES, J.A., 2006. DNA damage and repair in haemolymph cells of golden mussel (Limnoperna fortunei) exposed to environmental contaminants. Mutation Research, vol. 605, no. 1-2, pp. 78-86. http://dx.doi.org/10.1016/j.mrgentox.2006.02.006. PMid:16697250. 